\title{
Insects in Atlantic salmon (Salmo salar) diets - comparison between full-fat, defatted, and de-chitinised meals, and oil and exoskeleton fractions
}

\author{
P. Weththasinghe ${ }^{1}$, J.Ø. Hansen ${ }^{1}$, M. Rawski ${ }^{2}$, D. Józefiak ${ }^{3}$, S. Ghimire ${ }^{1}$ and M. Øverland $^{1 *}$ (iD \\ ${ }^{1}$ Department of Animal and Aquacultural Sciences, Faculty of Biosciences, Norwegian University of Life Sciences, P.O. Box \\ 5003, $1432 \AA$ s. Norway; ${ }^{2}$ Division of Inland Fisheries and Aquaculture, Institute of Zoology, Faculty of Veterinary Medicine \\ and Animal Science, Poznań University of Life Sciences, ul. Wojska Polskiego 71C, 60-644, Poznań, Poland; ${ }^{3}$ Department of \\ Animal Nutrition, Faculty of Veterinary Medicine and Animal Science, Poznań University of Life Sciences, ul. Wotyńska 33, \\ 60-627, Poznań, Poland; margareth.overland@nmbu.no
}

Received: 18 May 2021 / Accepted: 18 November 2021

(c) 2021 Wageningen Academic Publishers

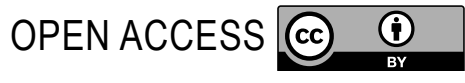

RESEARCH ARTICLE

\begin{abstract}
The present study investigated the effect of meals and fractions of black soldier fly larvae (BSFL; Hermetia illucens) in diets for Atlantic salmon (Salmo salar) on the physical quality of feed pellets, nutrient utilisation, and growth performance. Six extruded diets were produced: control diet (CD); full-fat BSFL meal diet (IM); defatted BSFL meal diet (DFIM); de-chitinised BSFL meal diet (DCIM); BSFL oil diet (IO) and BSFL exoskeleton diet (EX). The full-fat, defatted and de-chitinised meals replaced $15 \%$ of protein in the control diet. An eight-week study was conducted using salmon with average $28 \mathrm{~g}$ initial weight. The full-fat and de-chitinised meals in the diets numerically reduced pellet hardness, expansion, and water stability. The full-fat and de-chitinised meals improved growth rate of salmon, whilst defatted meal, oil and exoskeleton supported similar growth performance as the control. Feed intake and growth rate of fish fed full-fat meal diet were higher than those fed the other insect diets, but defatted meal gave a better feed conversion ratio than full-fat meal. Defatted meal, de-chitinised meal and exoskeleton reduced protein digestibility in fish, however; defatted meal increased the digested protein retention. In conclusion, use of full-fat BSFL meal improved feed intake and growth rate of salmon when replacing $15 \%$ of dietary protein. The present results suggest that less processed fullfat form of BSFL is more optimal in diets for salmon and further processing to remove lipid or exoskeleton fractions would only lead to an additional cost.
\end{abstract}

Keywords: black soldier fly larvae, insect fractions, pellet quality, fish growth performance, nutrient utilisation

\section{Introduction}

Black soldier fly larvae (BSFL) (Hermetia illucens) have a great potential as a sustainable novel feed ingredient in fish feed due to its high nutrient value (Barroso et al., 2014; Makkar et al., 2014; Nogales-Mérida et al., 2019) and its ability to utilise wide variety of organic materials efficiently (Wang and Shelomi, 2017). Numerous studies reported the effect of dietary inclusion of BSFL on nutrient utilisation, growth performance, and health of various fish species including Atlantic salmon (Salmo salar) (Belghit et al., 2018, 2019a; Fisher et al., 2020; Lock et al., 2016; Weththasinghe et al., 2021a,b).
BSFL contain the three major fractions; protein, lipid and exoskeleton (Müller et al., 2017; Ravi et al., 2020). The results of previous studies suggest that these fractions might differently affect the nutrient utilisation and growth performance of fish. Dietary inclusion of moderate levels of BSFL meal $(<20 \%)$ did not compromise growth performance in salmon (Belghit et al., 2019a; Fisher et al., 2020; Weththasinghe et al., 2021a), whereas higher inclusion levels $(>20 \%)$ reduced growth rate (Fisher et al., 2020; Weththasinghe et al., 2021a). In contrast, Belghit et al. (2018) reported that de-chitinised BSFL protein meal in diets did not compromise the growth performance of salmon even at $60 \%$ inclusion level. The reduction of growth rate at higher BSFL levels was thus suggested to 
be attributed to the presence of chitin in the exoskeleton of BSFL (Dumas et al., 2018; Weththasinghe et al., 2021a). Dietary inclusion of BSFL meal has also shown to reduce the nutrient digestibility in salmon (Belghit et al., 2018; Weththasinghe et al., 2021a). This might also be due to chitin (Hansen et al., 2010; Karlsen et al., 2017; Shiau and Yu, 1999) or high level of saturated fatty acids (Hua and Bureau, 2009) present in BSFL. Further, Weththasinghe et al. (2021a) reported that the lipid retention decreased at high dietary inclusion of BSFL meal in salmon. It was hypothesised that this was caused by high level of lauric acid (C12:0) in BSFL, which is preferred as a substrate for oxidation in salmon (Belghit et al., 2019b; Renna et al., 2017). On the other hand, bioactive compounds present in BSFL, such as antimicrobial peptides (Müller et al., 2017; Park et al., 2014, 2015), chitin, as well as lauric acid possess antimicrobial properties (Askarian et al., 2012; Skřivanová et al., 2006; Spranghers et al., 2018), which could have a positive effect on gut microbiota, gut health and subsequently the growth performance in fish.

The quality and antimicrobial peptides in the protein fraction, fatty acid composition in the lipid fraction and the chitin in the exoskeleton fraction of BSFL might have contrasting effects on the nutrient utilisation and growth performance in fish. However, to the best of our knowledge, such effects of different fractions of BSFL have still not been evaluated in a single study. Further, limited information exists on the BSFL fractions on technical quality of extruded feed pellets. Therefore, the present study investigated the effects of meals (full-fat, defatted and de-chitinised) and fractions (oil and exoskeleton) of BSFL in extruded diets on physical pellet quality, nutrient utilisation, and growth performance in Atlantic salmon pre-smolts.

\section{Materials and methods}

\section{Rearing and processing of black soldier fly larvae}

BSFL were reared and processed into meals or fractions at HiProMine S.A., Robakowo, Poland. The BSFL were fed ad libitum. The dry matter (DM) content of BSFL feed was normalised to $22 \%$ by adding wheat middlings (17\%) to fresh vegetables and fruit pre-consumer waste mix, consisting of apples (15\%), carrots (50\%), potatoes $(15 \%)$, and cabbage (20\%). The feed mixture was ground (2,000 rpm, 55 kW; HPM milling system, HiProMine S.A.) to sieve through a $2 \mathrm{~mm}$ screen. In accordance with EC regulation (no 1069/09), the BSFL feed did not contain any animal products.

The larvae were harvested on the seventh day of rearing, sieved using a $3 \mathrm{~mm}$ screen, and washed with water on drum separator at $90^{\circ} \mathrm{C}$ for $10 \mathrm{~min}$ (HPM cleaning system, HiProMine S.A.). A batch of BSFL was divided into two parts for further processing. The first part was dried at $110{ }^{\circ} \mathrm{C}$ for $1 \mathrm{~h}$ and then at $80^{\circ} \mathrm{C}$ for $23 \mathrm{~h}$ until a constant weight was reached using a chamber air flow dryer (HiProMine S.A.) for full-fat BSFL meal production, then a part of it was defatted to obtain partially defatted meal and oil with use of oil press (Reinartz, model AP14/22, Neuss, Germany). The second part of BSFL was used to obtain partially dechitinised meal and exoskeleton fraction. For the separation of partially de-chitinised BSFL and exoskeleton fraction, the mechanical de-chitinisation was applied using food press twin-screw processor with $0.3 \mathrm{~mm}$ screen diameter (Angel Juicer, model 7500, Busan, Korea). The de-chitinised BSFL and exoskeleton were dried at $110^{\circ} \mathrm{C}$ for $1 \mathrm{~h}$ and then at $80^{\circ} \mathrm{C}$ for $23 \mathrm{~h}$ until a constant weight was reached using a chamber air flow dryer (HiProMine S.A.). All the products were stored at $4{ }^{\circ} \mathrm{C}$ before use for feed production. The chemical compositions of BSFL ingredients are shown in Table 1 and Table S1.

\section{Experimental diets}

Six experimental diets were formulated to have similar amino acid profiles and lipid contents, and to meet NRC (2011) requirements for all essential amino acids and other nutrients for Atlantic salmon. The experimental diets comprised of a control diet (CD) containing fishmeal, soy protein concentrate (SPC) and corn gluten as protein sources, and fish oil as the main lipid source; three diets with full-fat BSFL meal (IM), defatted BSFL meal (DFIM) or de-chitinised BSFL meal (DCIM), replacing 15\% of protein from fishmeal, SPC and corn gluten in the control diet; a diet containing BSFL oil (IO) and a diet containing BSFL exoskeleton (EX). The BSFL oil and exoskeleton were added to the diets to match the BSFL oil and chitin contents in full-fat BSFL meal diet, respectively. The internal marker, Yttrium oxide was added in all the diets for the determination of apparent digestibility coefficient (ADC) of nutrients. Crystalline methionine and monocalcium phosphate were added to all the diets to ensure that the diets met or exceeded the methionine (0.7\%, DM basis (NRC, 2011)) and phosphorous (P) (0.8\%, DM basis (NRC, 2011)) requirements of Atlantic salmon, respectively. Table 2 shows the ingredient and chemical composition of the six experimental diets.

\section{Production of experimental diets}

The extruded experimental diets were produced at the Norwegian University of Life Sciences (NMBU) Centre for Feed Technology (Fôrtek), Ås, Norway. First, all the weighed ingredients (except micro ingredients, fish oil and BSFL oil) were mixed for $3 \mathrm{~min}$ in an ISDECA mixer (60-1 paddle-mixer, prototype, Fôrtek, Forberg, Norway). The material mixture was then ground in a Hammer mill (Bill bliss, horizontal, $18.5 \mathrm{~kW}$, USA) with a $1 \mathrm{~mm}$ sieve, and mixed with micro-ingredients. The feed mash of full-fat and de-chitinised meal diets were ground again 
Table 1. Chemical composition (\%, as is) of meals and fractions of black soldier fly larvae (BSFL).

\begin{tabular}{|c|c|c|c|c|c|}
\hline Nutrient & Full-fat BSFL meal & Defatted BSFL meal & De-chitinised BSFL meal & BSFL oil & BSFL exoskeleton \\
\hline Dry matter & 88.1 & 86.8 & 90.7 & 99.0 & 91.7 \\
\hline Crude protein & 37.6 & 51.4 & 31.2 & 2 & 59.9 \\
\hline Crude lipid & 29.6 & 11.7 & 43.5 & $96.0^{1}$ & 11.1 \\
\hline Ash & 5.82 & 8.03 & 6.97 & 1.03 & 5.59 \\
\hline Chitin & 7.05 & 9.65 & 2.15 & & 19.8 \\
\hline \multicolumn{6}{|l|}{ Amino acids ${ }^{2}$} \\
\hline \multicolumn{6}{|c|}{ Essential amino acids } \\
\hline Methionine & 0.41 & 0.56 & 0.42 & NA & 0.29 \\
\hline Threonine & 1.16 & 1.58 & 1.10 & NA & 1.71 \\
\hline Valine & 1.46 & 1.99 & 1.33 & NA & 2.75 \\
\hline Isoleucine & 1.23 & 1.68 & 1.17 & NA & 1.91 \\
\hline Leucine & 2.02 & 2.75 & 1.91 & NA & 3.11 \\
\hline Phenylalanine & 1.24 & 1.69 & 1.19 & NA & 1.73 \\
\hline Histidine & 0.95 & 1.30 & 0.88 & NA & 1.70 \\
\hline Lysine & 1.92 & 2.62 & 1.90 & NA & 2.14 \\
\hline Arginine & 1.48 & 2.03 & 1.42 & NA & 2.09 \\
\hline Tryptophan & 0.22 & 0.29 & 0.23 & NA & 0.10 \\
\hline \multicolumn{6}{|c|}{ Non-essential amino acids } \\
\hline Cysteine & 0.23 & 0.32 & 0.23 & NA & 0.24 \\
\hline Aspartic acid & 2.48 & 3.39 & 2.40 & NA & 3.34 \\
\hline Serine & 1.27 & 1.73 & 1.17 & NA & 2.30 \\
\hline Glutamic acid & 3.97 & 5.42 & 3.78 & NA & 5.89 \\
\hline Proline & 1.96 & 2.68 & 1.78 & NA & 3.87 \\
\hline Glycine & 1.52 & 2.08 & 1.37 & NA & 3.07 \\
\hline Alanine & 2.25 & 3.07 & 2.07 & NA & 4.01 \\
\hline Tyrosine & 2.56 & 3.50 & 2.25 & NA & 5.74 \\
\hline Total amino acid & 28.33 & 38.68 & 26.61 & NA & 45.97 \\
\hline
\end{tabular}

in the Hammer mill (Bill bliss, horizontal, $18.5 \mathrm{~kW}$, USA) with a $0.5 \mathrm{~mm}$ sieve to prevent the production of coarse particles and less integrated pellets after the extrusion. The diets were extruded in a five-section Bühler twinscrew extruder (BCTG 62/20 D, Uzwil, Switzerland) fitted with four $2.5 \mathrm{~mm}$ die holes. The extruder operated without a pre-conditioner and the screw configuration shown previously by Weththasinghe et al. (2021a) was used during the extrusion of diets. The feed mash was fed into the first section of the extruder using a small K-tron feeder. The screw speed was increased when the extrusion of insect ingredients containing diets. The extruded pellets were dried at $60^{\circ} \mathrm{C}$ for $1 \mathrm{~h}$ using fan heaters $(15 \mathrm{KW}$, Inelco heaters, Dania-heater $15 \mathrm{~kW}$, Fjerritslev, Denmark). The pellets were then cooled at room temperature and vacuum coated with fish oil and/or BSFL oil in Gentle Vacuum Coater -80 prototype (Fôrtek, Amandus-Kahl).

\section{Fish study, rearing facilities, and sampling}

The fish study was conducted at the Centre for Fish Research, NMBU, Ås, Norway. The study consisted of 900 Atlantic salmon (Aqua Gen Atlantic QLT-innOva SHIELD) with an average $28 \mathrm{~g}$ initial weight. The fish were randomly distributed into 18 fiberglass tanks (50 fish per tank) with recirculated freshwater (average temperature of $14.4 \pm 0.4^{\circ} \mathrm{C}$ ). The tanks were supplied with water at $6 \mathrm{l} / \mathrm{min}$ and dissolved oxygen levels were kept above $7.0 \mathrm{mg} / \mathrm{l}$ in the outlet water. The study lasted for eight weeks and triplicate tanks of salmon were fed one of the six experimental diets. The fish were kept under continuous light and fed ad libitum (i.e. 10\% excess) with electrically driven belt feeders according to a six-hours feeding program per day. The uneaten feed was collected daily using the wedge wire screens fitted to the outlet of tanks as explained by Shomorin et al. (2019) and daily feed intake in each tank 
Table 2. Ingredient and chemical composition of experimental diets ${ }^{1}$ with meals or fractions of black soldier fly larvae (BSFL).

\begin{tabular}{|c|c|c|c|c|c|c|}
\hline Ingredients $(\%)^{2}$ & CD & IM & DFIM & DCIM & 10 & EX \\
\hline Fishmeal $^{\mathrm{a}}$ & 22.50 & 18.57 & 18.57 & 18.57 & 22.50 & 21.78 \\
\hline Soy protein concentrate ${ }^{\mathrm{b}}$ & 34.50 & 28.48 & 28.48 & 28.48 & 34.50 & 33.39 \\
\hline Corn gluten ${ }^{c}$ & 5.50 & 4.54 & 4.54 & 4.54 & 5.50 & 5.32 \\
\hline Full-fat BSFL meal $^{d}$ & 0.00 & 20.36 & 0.00 & 0.00 & 0.00 & 0.00 \\
\hline Defatted BSFL meale & 0.00 & 0.00 & 14.89 & 0.00 & 0.00 & 0.00 \\
\hline De-chitinised BSFL mealf & 0.00 & 0.00 & 0.00 & 24.53 & 0.00 & 0.00 \\
\hline BSFL oilg & 0.00 & 0.00 & 0.00 & 0.00 & 6.24 & 0.00 \\
\hline BSFL exoskeleton ${ }^{h}$ & 0.00 & 0.00 & 0.00 & 0.00 & 0.00 & 7.20 \\
\hline Wheat flour' & 14.65 & 14.65 & 14.65 & 14.65 & 14.65 & 14.65 \\
\hline Fish oil & 16.00 & 10.47 & 14.75 & 5.82 & 10.05 & 15.36 \\
\hline Methionine ${ }^{k}$ & 0.20 & 0.20 & 0.20 & 0.20 & 0.20 & 0.20 \\
\hline Choline chloride & 0.15 & 0.15 & 0.15 & 0.15 & 0.15 & 0.15 \\
\hline Yttrium $^{m}$ & 0.01 & 0.01 & 0.01 & 0.01 & 0.01 & 0.01 \\
\hline Vit/min premix ${ }^{n}$ & 0.65 & 0.65 & 0.65 & 0.65 & 0.65 & 0.65 \\
\hline Monocalcium Phosphate ${ }^{\circ}$ & 0.80 & 0.80 & 0.80 & 0.80 & 0.80 & 0.80 \\
\hline Wheat bran ${ }^{p}$ & 5.04 & 1.12 & 2.31 & 1.60 & 4.75 & 0.49 \\
\hline \multicolumn{7}{|c|}{ Chemical composition ( $\%$, as is) } \\
\hline Dry matter & 91.6 & 91.9 & 93.0 & 92.9 & 93.3 & 91.7 \\
\hline Crude protein & 46.6 & 44.4 & 46.0 & 46.6 & 46.6 & 47.3 \\
\hline Crude lipid & 19.6 & 20.3 & 17.8 & 12.9 & 18.3 & 17.0 \\
\hline Starch & 13.1 & 12.2 & 12.4 & 12.4 & 12.6 & 11.7 \\
\hline Ash & 6.70 & 6.60 & 6.77 & 7.23 & 6.70 & 6.61 \\
\hline Chitin 9 & & 1.44 & 1.44 & 0.53 & & 1.43 \\
\hline \multicolumn{7}{|c|}{ Macro mineral composition ( $\%$, as is) } \\
\hline Total phosphorous & 1.13 & 1.10 & 1.10 & 1.24 & 1.11 & 1.10 \\
\hline Calcium & 1.11 & 1.19 & 1.29 & 1.28 & 1.28 & 1.19 \\
\hline Magnesium & 0.18 & 0.19 & 0.20 & 0.23 & 0.17 & 0.17 \\
\hline \multicolumn{7}{|c|}{ Amino acid composition ${ }^{r}$ (\%, as is) } \\
\hline \multicolumn{7}{|l|}{ Essential amino acids } \\
\hline Methionine & 0.98 & 0.90 & 0.90 & 0.94 & 0.90 & 0.94 \\
\hline Threonine & 1.59 & 1.48 & 1.51 & 1.56 & 1.58 & 1.59 \\
\hline Valine & 1.55 & 1.52 & 1.54 & 1.51 & 1.56 & 1.64 \\
\hline Isoleucine & 1.78 & 1.65 & 1.70 & 1.75 & 1.80 & 1.79 \\
\hline Leucine & 3.40 & 3.05 & 3.12 & 3.23 & 3.40 & 3.36 \\
\hline Phenylalanine & 1.99 & 1.76 & 1.81 & 1.90 & 1.97 & 1.88 \\
\hline Histidine & 1.07 & 1.04 & 1.05 & 1.06 & 1.07 & 1.09 \\
\hline Lysine & 2.62 & 2.47 & 2.49 & 2.59 & 2.60 & 2.58 \\
\hline Arginine & 2.72 & 2.42 & 2.46 & 2.57 & 2.71 & 2.63 \\
\hline \multicolumn{7}{|l|}{ Non-essential amino acids } \\
\hline Cysteine & 0.45 & 0.41 & 0.41 & 0.43 & 0.44 & 0.43 \\
\hline Aspartic acid & 4.13 & 3.68 & 3.82 & 3.99 & 4.12 & 4.05 \\
\hline Serine & 1.84 & 1.66 & 1.71 & 1.71 & 1.80 & 1.85 \\
\hline Glutamic acid & 8.05 & 7.08 & 7.32 & 7.55 & 8.00 & 7.90 \\
\hline Proline & 2.12 & 2.05 & 2.17 & 2.07 & 2.16 & 2.32 \\
\hline Glycine & 1.70 & 1.64 & 1.67 & 1.63 & 1.69 & 1.78 \\
\hline Alanine & 1.96 & 1.99 & 2.02 & 1.91 & 1.96 & 2.11 \\
\hline Tyrosine & 1.21 & 1.41 & 1.43 & 1.24 & 1.25 & 1.48 \\
\hline Total amino acid & 39.2 & 36.2 & 37.1 & 37.6 & 39.0 & 39.4 \\
\hline
\end{tabular}

${ }^{1} \mathrm{CD}=$ Control diet; DCIM = De-chitinised BSFL meal diet; DFIM = Defatted BSFL meal diet; EX = BSFL exoskeleton diet; $I M=$ Full-fat BSFL meal diet; $10=$ BSFL oil diet.

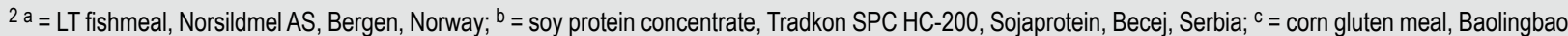
Biology, Shangdong Yucheng, China; ${ }^{d}=$ full-fat BSFL meal, HiProMine S.A., Poznań, Poland; ${ }^{e}=$ defatted BSFL meal, HiProMine S.A., Poznań, Poland; ${ }^{f}=$ dechitinised BSFL meal, HiProMine S.A., Poznań, Poland; 9 = BSFL oil, HiProMine S.A., Poznań, Poland; ${ }^{\text {h }}=$ BSFL exoskeleton, HiProMine S.A., Poznań, Poland; $i$ = wheat flour 78\%, batch number: 5093060546 , Norgesmøllene, Bergen, Norway; ${ }^{j}=$ fish oil, Norsildmel AS, Bergen, Norway; ${ }^{k}=$ L-methionine, Bestamino ${ }^{\mathrm{TM}}$ Cj Cheiljedang, Seoul, Korea; ${ }^{l}=$ choline chloride $70 \%, \mathrm{C}_{5} \mathrm{H}_{14} \mathrm{CINO}, 139.6 \mathrm{~g} / \mathrm{mol}$, Vilomix, Hønefoss, Norway; ${ }^{\mathrm{m}}=$ yttrium oxide $\left(\mathrm{Y}_{2} \mathrm{O}_{3}\right)$ Metal Rare Earth Limited, Shenzhen, China; ${ }^{\mathrm{n}}=$ vit/min premix, Farmix, Trouw Nutrition, LA Putten, the Netherlands. Per kg of feed; Vitamin A 3,250 IU, Vitamin D3 1,950 IU, Vitamin E 260 IU, Vitamin K3 13 mg, Vitamin B1 20 mg, Vitamin B2 33 mg, d-Ca-pantothenate 52 mg, Niacinamide 98 mg, Vitamin B6 20 mg, Folic acid 6.5 mg, Vitamin B12 33 g, Vitamin C $163 \mathrm{mg}$, Biotin $358 \mu \mathrm{g}$, Calcium iodate, anhydrous, lodine $3.9 \mathrm{mg}$, Manganese (II) oxide, Manganese $20 \mathrm{mg}$, Zinc oxide, Zinc $137 \mathrm{mg} ;{ }^{\circ}=\mathrm{monocalcium}$

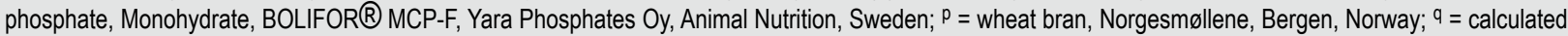
based on the chitin content of the respective BSFL ingredient and its inclusion level in the diet; ${ }^{r}=$ water corrected values. 
was quantified according to Helland et al. (1996). The fish mortality was checked daily. Initial and final body weights of fish were measured at the start and end of the eight-week study period. Fifteen fish at the start and five fish per tank at end of the study were sampled, pooled, homogenised and freeze dried for whole body composition analysis. In addition, at the end of the study, another six fish from each tank were randomly sampled, anaesthetised, euthanised by a sharp blow to the head and weighed individually. The fish were dissected, and the liver was removed. The attached adipose tissue and fat around liver were removed and the liver weight was measured to calculate hepatosomatic index (HSI). After the eight-week study period, fish were fed with experimental diets for two additional weeks for faeces collection. Fish were carefully stripped three times with seven days interval for faecal collection from the posterior intestine according to Austreng (1978). The stripped faeces were stored immediately at $-20^{\circ} \mathrm{C}$ prior to freeze drying. Tricaine methanesulfonate (MS-222) $(80 \mathrm{mg} / \mathrm{l})$ was used to anaesthetise fish during weighing, sampling, and stripping. All the experimental procedures were conducted adhering to the guidelines for the care and use of animals in Norway (The Norwegian Animal Welfare Act and the Norwegian Regulation and Animal Experimentation).

\section{Physical pellet quality analysis}

The bulk density of the uncoated pellets was measured after the extrusion. The other physical quality parameters were measured in oil-coated pellets. As explained by Hansen et al. (2010), Doris pellet tester (AKVAsmart, Bryne, Norway) was used to estimate pellet durability. The durability of the pellets was measured in triplicates using a $2 \mathrm{~mm}$ screen. Hardness was measured using 15 pellets with average length and diameter from each diet with a Texture analyser with a $5 \mathrm{~kg}$ load cell (Tinius Olsen, H5KT, Salfords, UK) according to Øverland et al. (2009). The expansion of the extruded pellets was determined by measuring the width of 30 randomly selected pellets per diet using the Texture analyser (Tinius Olsen, H5KT). The mean value of the time required for 10 randomly picked pellets to sink $1 \mathrm{~m}$ in $17^{\circ} \mathrm{C}$ tap water was recorded to determine the sinking velocity of the pellets. The method explained by Baeverfjord et al. (2006) was used to measure the water stability of pellets within 30 and $60 \mathrm{~min}$.

\section{Chemical analysis}

The feed and freeze-dried faeces and fish were ground. The samples were oven dried at $104{ }^{\circ} \mathrm{C}$ until a constant weight was reached to measure DM content. Ash contents were determined by combustion at $550{ }^{\circ} \mathrm{C}$. The nitrogen (N) contents of BSFL ingredients and fish were estimated by Kjeldahl method according to Commission Regulation (EC) No 152/ 2009. The N contents of faeces were analysed by CHNS Elemental Analyzer (Vario El Cube elemental analyser system $\mathrm{GmbH}$, Hanau, Germany). The crude protein content was determined as $\mathrm{N} \times 6.25$. The $\mathrm{N}$ content in diets was measured by both methods and the values obtained by CHNS Elemental Analyzer were used for protein digestibility estimates, whereas the values obtained by Kjeldahl method were used for protein retention estimates. The chitin contents of BSFL ingredients were measured as explained by Finke (2007). In brief, acid detergent fibre (ADF) content and the percentage of amino acids in the ADF rest fraction was measured. The ADF content was corrected for the sum of amino acids and the remainder of the ADF fraction was considered as chitin. The crude lipid contents of BSFL ingredients, faeces and fish were determined after extraction with petroleum ether and acetone (70/30) using an Accelerated Solvent Extractor (ASE200; Dionex Corp., Sunnyvale, CA, USA). The crude lipid contents of diets were measured by acid hydrolysis and ether extraction according to NMKL 160 (modified) at Eurofins Agro Testing Norway AS, Moss, Norway. The method explained by McCleary et al. (1994) was used with some modifications to measure starch content. Briefly, the starch in the samples were converted into glucose using heat-stable $\alpha$-amylase and amyl glucosidase-enzymes, and glucose content was measured by a spectrometer (RX4041 Randox Daytona+, Randox Laboratories, Antrim, UK). The Biochrom 30 Amino Acid Analyser (Biochrom Ltd., Cambridge, UK) was used to analyse amino acid contents according to Commission Regulation (EC) No 152/2009. The fatty acid content of BSFL oil was determined by synthesising the fatty acid to fatty acid methyl esters using Trace GC Ultra gas chromatograph (Thermo Fisher Scientific, Waltham, MA, USA) as explained by O'Fallon et al. (2007). Yttrium (Y), calcium and magnesium contents were measured after acid decomposition in a microwave digestion system (Start D, Milestone Srl, Sorisole, Italy) using a microwave plasma atomic emission spectrometer (MP-AES 4200, Agilent Technologies, Santa Clara, CA, USA). Total $\mathrm{P}$ contents were analysed using a commercial spectrophotometric kit (PH8328, Randox Laboratories) after combustion and acid digestion according to Commission Regulation (EC) No 152/2009.

\section{Calculations}

The pellet expansion (\%) was calculated as ((Width of pellet - Die diameter) $/$ Die diameter $) \times 100$. Specific mechanical energy $(\mathrm{Wh} / \mathrm{kg})$ was calculated as $\left(2 \times \pi \times 60^{-1}\right) \times($ Screw speed $\times$ Torque $\times$ Throughput). Specific growth rate (SGR) (\%) was calculated as [(ln (Fish final body weight (g)) ln (Fish initial body weight (g))) / Study period (days)] $\times$ 100. Feed conversion ratio (FCR) was calculated as Feed intake of fish (g DM) / Fish body weight gain (g). HSI (\%) was calculated as Weight of liver (g)/Fish body weight $(\mathrm{g}) \times 100$. ADC of nutrients (\%) was calculated as $(1-[(\mathrm{Y}$ concentration in diet / Y concentration in faeces $) \times($ Nutrient concentration in faeces / Nutrient concentration in diet)]) 
$\times 100$. Faecal excretion of nutrients (\%) was calculated as (100 - ADC of nutrients). The dissolved nutrient fraction $(\mathrm{g} / \mathrm{kg})$ was calculated as [Nutrient digested $(\mathrm{g})$ - (Final nutrient content in fish $(\mathrm{g})$ - Initial nutrient content in fish $(\mathrm{g}))$ ] / Fish body weight gain $(\mathrm{kg})$. Protein and lipid efficiency ratios were calculated as Fish body weight gain (g) / Protein or lipid intake (g). Apparent nutrient retention (\% intake) was calculated as [(Final nutrient content in fish (g) - Initial nutrient content in fish (g)) / Nutrient intake $(\mathrm{g})] \times 100$. Nutrient retention (\% digested nutrient) was calculated as [(Final nutrient content in fish (g) - Initial nutrient content in fish (g)) / Nutrient digested $(\mathrm{g})] \times 100$.

\section{Statistical analysis}

The data were analysed using one-way ANOVA and Tukey's multiple comparison test was used to compare the means. Differences at $P<0.05$ were regarded as significant. The analyses were performed using IBM SPSS Statistics 27 software (IBM Corp., Armonk, NY, USA).

\section{Results}

\section{Feed production and physical pellet quality}

The lipid-rich full-fat and de-chitinised insect meals increased the lipid content of the feed mash prior to extrusion. To compensate for this, the throughput and water addition to the extruder were increased to obtain pellets with desirable physical quality in the full-fat and de-chitinised insect meals included diets. In addition, the fifth barrel of the extruder was cooled to obtain the desired bulk density in these two diets, and this led to reduced temperature in the fifth barrel and the die. Further, decreased die pressure and torque were observed during the extrusion process of these two diets (Table 3 ).

The pellet durability measured by the Doris pellet tester showed an overall high physical quality of the pellets. However, the full-fat and de-chitinised insect meal included diets showed numerically lower pellet hardness, expansion, and water stability as well as numerically higher bulk density after the extrusion (Table 4 and Figure 1).

\section{Growth performance}

Only four fish died throughout the study period. The fish fed full-fat insect meal showed higher feed intake, accompanied by higher final body weight and SGR compared with the fish fed the control and the other insect diets. In addition, the inclusion of de-chitinised insect meal in the diet also increased final body weight and SGR of fish compared to the control diet but decreased compared to the full-fat meal diet. The defatted insect meal, oil and exoskeleton supported similar final body weight and SGR as the control diet fed fish. Although the FCR of the fish fed insect diets did not differ from the fish fed control diet, defatted meal and exoskeleton included diets gave lower FCR in fish than the full-fat meal diet. The HSI was not affected by the dietary treatments (Table 5).

Table 3. Extruder parameters during the production of experimental diets ${ }^{1}$ with meals or fractions of black soldier fly larvae (BSFL).

\begin{tabular}{|c|c|c|c|c|c|c|}
\hline Extruder parameter ${ }^{2}$ & $C D$ & IM & DFIM & DCIM & 10 & EX \\
\hline Throughput (kg/h) & 35 & 40 & 30 & 40 & 30 & 30 \\
\hline Barrel $1\left({ }^{\circ} \mathrm{C}\right)$ & 42 & 22 & 32 & 26 & 37 & 40 \\
\hline Barrel $2\left({ }^{\circ} \mathrm{C}\right)$ & 86 & 33 & 49 & 37 & 60 & 77 \\
\hline Barrel $3\left({ }^{\circ} \mathrm{C}\right)$ & 107 & 67 & 108 & 84 & 114 & 113 \\
\hline Barrel $4\left({ }^{\circ} \mathrm{C}\right)$ & 113 & 107 & 123 & 105 & 127 & 123 \\
\hline Barrel $5\left({ }^{\circ} \mathrm{C}\right)$ & 111 & 84 & 122 & 92 & 127 & 122 \\
\hline Die temperature $\left({ }^{\circ} \mathrm{C}\right)$ & 105 & 91 & 122 & 99 & 127 & 122 \\
\hline Die pressure (Bar) & 23 & 4 & 12.3 & 2.8 & 25.2 & 22.4 \\
\hline Screw speed (rpm) & 270 & 400 & 400 & 425 & 385 & 400 \\
\hline Torque (\%) & 53 & 43 & 48 & 38 & 60 & 49 \\
\hline Drive power (kW) & 6.5 & 7.6 & 8.8 & 7.3 & 10.7 & 9 \\
\hline $\operatorname{SME}^{\mathrm{a}}(\mathrm{Wh} / \mathrm{kg})$ & 449 & 510 & 616 & 440 & 771 & 630 \\
\hline Water addition ${ }^{b}(\mathrm{~kg} / \mathrm{h})$ & 14 & 15.5 & 14 & 16.5 & 14 & 14 \\
\hline Lipid (\%) & 2.50 & 7.97 & 3.75 & 12.64 & 2.48 & 3.01 \\
\hline
\end{tabular}

${ }^{1} \mathrm{CD}=$ Control diet; $\mathrm{DCIM}=$ De-chitinised BSFL meal diet; DFIM = Defatted BSFL meal diet; $\mathrm{EX}=\mathrm{BSFL}$ exoskeleton diet; $I \mathrm{IM}=$ Full-fat BSFL meal diet; $I O=$ BSFL oil diet.

$2 \mathrm{a}=$ specific mechanical energy; ${ }^{\mathrm{b}}=$ water added into the extruder ${ }^{\mathrm{c}}=$ percentage of lipid in the feed mash prior to extrusion. 
Table 4. Physical pellet quality of experimental diets ${ }^{1}$ with meals or fractions of black soldier fly larvae (BSFL).

\begin{tabular}{|c|c|c|c|c|c|c|c|}
\hline Pellet quality parameter ${ }^{2}$ & $C D$ & IM & DFIM & DCIM & 10 & EX & SEM $^{3}$ \\
\hline Bulk density $(g / l)^{a}$ & 566.7 & 586.3 & 540.3 & 580 & 528.7 & 560.7 & 5.36 \\
\hline Durability $(\%)^{a}$ & 97.7 & 96.4 & 98.0 & 93.7 & 98.6 & 98.3 & 0.42 \\
\hline Hardness $(\mathrm{N})^{b}$ & 18.2 & 12.3 & 13.4 & 11.1 & 23.6 & 14.0 & 0.82 \\
\hline Expansion $(\%)^{c}$ & 18.4 & 1.67 & 17.4 & -0.81 & 32.3 & 21.8 & 0.89 \\
\hline Sinking velocity $(\mathrm{m} / \mathrm{s})^{d}$ & 0.10 & 0.08 & 0.09 & 0.08 & 0.08 & 0.09 & 0.002 \\
\hline
\end{tabular}

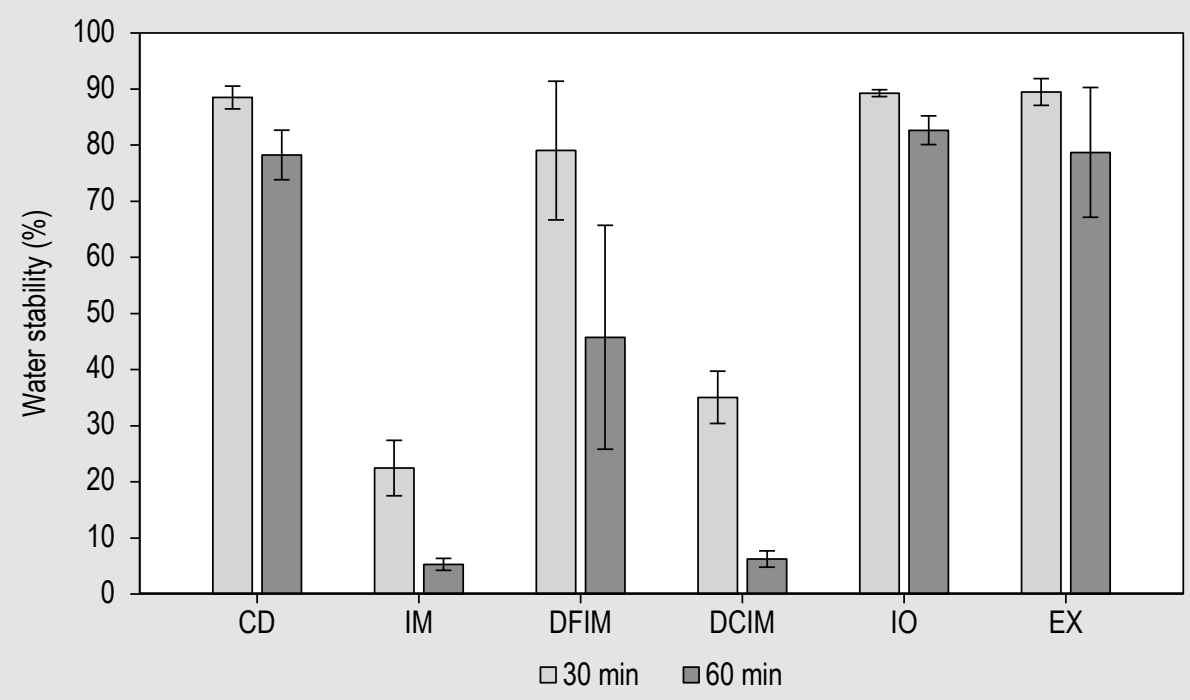

Figure 1. Water stability (dry matter retention \%) of pellets of experimental diets with meals or fractions of black soldier fly larvae (BSFL) within $30 \mathrm{~min}$ and $60 \mathrm{~min}$ (mean of 3 observations). Error bars indicate standard deviation. CD: Control diet. IM: Full-fat BSFL meal diet. DFIM: Defatted BSFL meal diet. DCIM: De-chitinised BSFL meal diet. IO: BSFL oil diet. EX: BSFL exoskeleton diet.

Table 5. Performance of fish fed experimental diets ${ }^{1}$ with meals or fractions of black soldier fly larvae (BSFL). ${ }^{2}$

\begin{tabular}{|c|c|c|c|c|c|c|c|c|}
\hline & CD & IM & DFIM & DCIM & 10 & EX & SEM $^{3}$ & $P$-value \\
\hline Initial body weight (g) & 28.3 & 28.3 & 28.3 & 28.3 & 28.3 & 28.3 & 0.007 & 0.14 \\
\hline Final body weight (g) & $98.4^{\mathrm{c}}$ & $114.8^{\mathrm{a}}$ & $104.2^{b c}$ & $107.1^{b}$ & $99.8^{b c}$ & $104.7^{b c}$ & 1.41 & $<0.001$ \\
\hline Specific growth rate (\%) & $2.01^{c}$ & $2.26^{\mathrm{a}}$ & $2.10^{\mathrm{bc}}$ & $2.14^{b}$ & $2.03^{b c}$ & $2.11^{b c}$ & 0.02 & $<0.001$ \\
\hline Feed intake (g DM/fish) & $53.1^{\mathrm{b}}$ & $68.8^{a}$ & $55.9^{b}$ & $59.4^{b}$ & $55.7^{b}$ & $57.1^{\mathrm{b}}$ & 1.31 & $<0.001$ \\
\hline Feed conversion ratio & $0.76^{\mathrm{ab}}$ & $0.80^{\mathrm{a}}$ & $0.74^{b}$ & $0.76^{a b}$ & $0.78^{a b}$ & $0.75^{b}$ & 0.006 & 0.013 \\
\hline Hepatosomatic index $(\%)^{4}$ & 1.32 & 1.35 & 1.42 & 1.36 & 1.34 & 1.37 & 0.01 & 0.48 \\
\hline
\end{tabular}

${ }^{1} \mathrm{CD}=$ Control diet; DCIM = De-chitinised BSFL meal diet; DFIM = Defatted BSFL meal diet; $E X=B S F L$ exoskeleton diet; IM = Full-fat BSFL meal diet; $I O=$ BSFL oil diet.

${ }^{2}$ Values in the same row with different superscripts are significantly different at $P<0.05$.

${ }^{3}$ Standard error mean $(n=3)$.

${ }^{4}$ Mean of 18 fish. 


\section{Digestibility, faecal excretion, and dissolved fraction of nutrients}

ADC of DM, crude lipid and starch were not affected by the dietary treatments. The full-fat insect meal and insect oil diets fed fish showed similar ADC of protein as the control diet fed fish. The defatted meal, de-chitinised meal and exoskeleton containing diets fed fish had lower ADC of protein, accompanied by increased faecal $\mathrm{N}$ excretion compared to the control diet fed fish. However, ADC of protein did not differ between full-fat insect meal diet and other insect diets (Table 6).

The fish fed full-fat and de-chitinised insect meals containing diets showed lower faecal excretion of $\mathrm{P}$, whereas fish fed full-fat meal, defatted meal and insect oil containing diets had lower faecal excretion of calcium, than the fish fed control diet. The dissolved fractions of $\mathrm{N}$ and $\mathrm{P}$ in insect meals or fractions containing diets did not differ from the control diet, except defatted meal diet, in which the dissolved fraction of $\mathrm{N}$ was lower than the control and full-fat meal diets. Further, the defatted insect meal fed fish showed a lower dissolved $P$ fraction compared to dechitinised insect meal diet fed fish (Table 6).

\section{Nutrient retention}

The retention of ingested protein was not affected by dietary treatments. The protein efficiency ratio of fish fed insect diets did not differ from the fish fed control diet. Further, the retentions of digested protein of fish fed insect diets, except defatted insect meal diet, were also similar as the fish fed control diet. In defatted insect meal diet, the retention of digested protein was higher compared to both control and full-fat insect meal diets. Fish fed the insect diets except full-fat meal diet showed higher lipid efficiency ratio (LER) than the control diet fed fish, where the fish fed de-chitinised meal showed the highest. The retention of both ingested and digested lipid in fish fed the insect diets did not differ from the control diet, except for those fed the de-chitinised meal diet, which had a higher retention of lipid. Both LER and lipid retentions were lower in the full-fat meal diet than the diets containing other insect meals or fractions. The apparent $P$ retention was higher in defatted insect meal diet fed fish compared to those fed control and other insect diets (Table 7).

\section{Discussion}

The present study investigated the effect of dietary inclusion of meals and fractions of BSFL on physical feed pellet quality, nutrient utilisation, and growth performance in Atlantic salmon pre-smolts. The results provide important information to determine how the BSFL should be processed to optimise its use in extruded diets for salmon.

\section{Feed production and physical pellet quality}

The high level of lipid in full-fat and de-chitinised insect meals increased the lipid content in the feed mash during extrusion. As explained in Weththasinghe et al. (2021a) and Hansen et al. (2011), increase in lipid content in the

Table 6. Apparent digestibility coefficient (\%), faecal excretion (\%) and dissolved fraction of nutrients $(\mathrm{g} / \mathrm{kg}$ of fish body weight gain) of fish fed experimental diets ${ }^{1}$ with meals or fractions of black soldier fly larvae (BSFL). ${ }^{2}$

\begin{tabular}{|c|c|c|c|c|c|c|c|c|}
\hline & CD & IM & DFIM & DCIM & 10 & EX & SEM $^{3}$ & $P$-value \\
\hline \multicolumn{9}{|c|}{ Apparent digestibility coefficients } \\
\hline Dry matter & 73.5 & 75.6 & 74.8 & 74.3 & 73.5 & 73.9 & 0.27 & 0.175 \\
\hline Crude protein & $89.4^{\mathrm{a}}$ & $88.0^{a b c}$ & $87.4^{b c}$ & $86.9^{c}$ & $89.0^{\mathrm{ab}}$ & $86.7^{c}$ & 0.28 & 0.001 \\
\hline Crude lipid & 97.6 & 97.6 & 97.1 & 95.7 & 96.9 & 97.1 & 0.23 & 0.16 \\
\hline Starch & 84.2 & 82.0 & 82.8 & 83.2 & 84.9 & 81.6 & 0.37 & 0.054 \\
\hline Ash & $21.8^{b}$ & $28.4^{\mathrm{ab}}$ & $31.0^{\mathrm{a}}$ & $28.0^{\mathrm{ab}}$ & $21.9^{b}$ & $25.7^{\mathrm{ab}}$ & 1.02 & 0.016 \\
\hline \multicolumn{9}{|c|}{ Faecal excretions } \\
\hline Phosphorous & $49.0^{\mathrm{ab}}$ & $43.2^{\mathrm{C}}$ & $43.5^{\mathrm{bc}}$ & $42.2^{\mathrm{c}}$ & $52.9^{a}$ & $47.8^{\mathrm{abc}}$ & 1.01 & $<0.001$ \\
\hline Calcium & $90.4^{\mathrm{a}}$ & $78.0^{\mathrm{b}}$ & $76.1^{b}$ & $82.5^{\mathrm{ab}}$ & $79.2^{b}$ & $83.3^{a b}$ & 1.30 & 0.002 \\
\hline Magnesium & 69.8 & 57.2 & 60.9 & 57.7 & 59.7 & 56.4 & 1.94 & 0.398 \\
\hline Nitrogen & $10.6^{c}$ & $12.0^{a b c}$ & $12.6^{\mathrm{ab}}$ & $13.2^{\mathrm{a}}$ & $11.0^{\mathrm{bc}}$ & $13.3^{a}$ & 0.28 & 0.001 \\
\hline \multicolumn{9}{|c|}{ Dissolved fractions } \\
\hline Nitrogen & $25.3^{a}$ & $25.0^{\mathrm{a}}$ & $21.5^{\mathrm{b}}$ & $23.2^{\mathrm{ab}}$ & $25.2^{\mathrm{a}}$ & $23.7^{a b}$ & 0.42 & 0.020 \\
\hline Phosphorous & $0.71^{\mathrm{ab}}$ & $0.91^{\mathrm{ab}}$ & $0.05^{b}$ & $1.06^{a}$ & $0.29^{a b}$ & $0.57^{\mathrm{ab}}$ & 0.11 & 0.020 \\
\hline
\end{tabular}


Table 7. Nutrient retention parameters in fish fed experimental diets ${ }^{1}$ with meals or fractions black soldier fly larvae (BSFL). ${ }^{2}$

\begin{tabular}{|c|c|c|c|c|c|c|c|c|}
\hline & CD & IM & DFIM & $\mathrm{DCIM}$ & 10 & EX & SEM $^{3}$ & $P$-value \\
\hline Protein efficiency ratio & $2.60^{\mathrm{ab}}$ & $2.61^{\mathrm{ab}}$ & $2.75^{a}$ & $2.64^{\mathrm{ab}}$ & $2.57^{\mathrm{b}}$ & $2.59^{a b}$ & 0.02 & 0.028 \\
\hline Lipid efficiency ratio & $6.17^{d}$ & $5.71^{e}$ & $7.10^{b}$ & $9.54^{\mathrm{a}}$ & $6.55^{\mathrm{C}}$ & $7.21^{b}$ & 0.30 & $<0.001$ \\
\hline Apparent protein retention (\% intake) & 48.4 & 47.4 & 50.5 & 48.6 & 48.6 & 48.3 & 0.32 & 0.087 \\
\hline Apparent protein retention ( $\%$ digested protein) & $54.1^{b}$ & $53.8^{b}$ & $57.8^{\mathrm{a}}$ & $56.0^{\mathrm{ab}}$ & $54.6^{\mathrm{ab}}$ & $55.7^{\mathrm{ab}}$ & 0.42 & 0.027 \\
\hline Apparent lipid retention (\% intake) & $88.3^{b c}$ & $77.9^{c}$ & $97.8^{\mathrm{b}}$ & $128.7^{a}$ & $96.7^{b}$ & $94.1^{b}$ & 3.91 & $<0.001$ \\
\hline Apparent lipid retention (\% digested lipid) & $90.4^{b c}$ & $79.8^{c}$ & $100.8^{b}$ & $134.5^{\mathrm{a}}$ & $99.7^{b}$ & $96.9^{b}$ & 4.21 & $<0.001$ \\
\hline Apparent phosphorous retention (\% intake) & $43.4^{b}$ & $47.2^{b}$ & $55.9^{\mathrm{a}}$ & $47.3^{b}$ & $44.0^{b}$ & $45.9^{b}$ & 1.16 & 0.003 \\
\hline
\end{tabular}

mash can result in reduced dough temperature and starch gelatinisation during extrusion, that further can lead to a lower physical quality of extruded pellets. This might explain the numerically lower hardness observed in full-fat and de-chitinised insect meals included diets in the present study. The higher bulk densities of full-fat and de-chitinised insect meal diets were accompanied by lower pellet expansion. The reduced pellet expansion in these two diets is in line with previous reports indicating that increased lipid content in feed mash decreased extrudate expansion (Hansen et al., 2011; Ilo et al., 2000; Weththasinghe et al., 2021a). High lipid levels in the feed mash can reduce the pressure during the extrusion, resulting in poor expansion (Ottoboni et al., 2018). In addition, the decreased pellet expansion in full-fat and de-chitinised insect meal diets might also be related to lower temperature in the fifth barrel of the extruder (Bandyopadhyay and Rout, 2001; Kothakota et al., 2013; Pathania et al., 2013). As shown by Hansen et al. (2011), the increased level of lipid content in the feed mash followed with reduced pellet expansion is also, most probably, explaining the reduced pellet water stability of full-fat and de-chitinised insect meal diets in the present study. Previous studies also showed reduced water stability of extruded fish feed pellets containing full-fat BSFL meal (Rawski et al., 2020; Weththasinghe et al., 2021a).

\section{Nutrient utilisation and growth performance in salmon}

In the present study, the replacement of $15 \%$ of dietary protein with full-fat insect meal, rather than with processed BSFL meal by separation of lipid or exoskeleton fractions supported higher growth rate, and is, thus, more resource efficient and less costly. The improvement in growth rate of fish fed the full-fat meal diet can be a result of the higher feed intake of fish fed this diet. The increased feed intake indicates that moderate level of full-fat BSFL meal in diets (20\%) might increase palatability for salmon. Rawski $e t$ al. (2020) also reported that dietary inclusion of full-fat
BSFL meal (10-30\%) increased feed acceptance in Siberian sturgeon (Acipenser baerii). In contrast, our previous study showed that $8-32 \%$ full-fat BSFL meal in diets had no effect on feed intake of salmon (Weththasinghe et al., 2021a). In the present study, the improved feed intake might be due to lower pellet water stability of full-fat meal diet as many water-soluble nutrients are known chemo-attractants and feed stimulants (Simon et al., 2021). In addition to the improved feed intake, other processes may also be involved in increase in growth rate of salmon fed full-fat insect meal in the present study. BSFL are rich in bioactive compounds such as chitin (Caligiani et al., 2018; Finke, 2013), antimicrobial peptides (Müller et al., 2017; Park et al., 2014, 2015) and medium-chain fatty acid, lauric acid (C12:0) (40\% of the total fatty acid) (Table S1). These compounds are shown to possess antimicrobial properties (Askarian et al., 2012; Skřivanová et al., 2006; Spranghers et al., 2018), which could have a positive effect on gut health and growth performance in fish. Thus, it is possible that the improved growth of fish fed full-fat meal diet might partially be due to the functional properties of BSFL protein, lipid, and exoskeleton fractions. However, in contrast to the present results, replacing $6.25-12.5 \%$ of dietary protein with full-fat BSFL meal had no effect on salmon growth rate, whereas replacing $25 \%$ of dietary protein had adverse effects on growth rate in our previous study (Weththasinghe et al., 2021a).

Previous studies reported that feeding krill meal containing chitin or chitin from shrimp shells reduced growth in salmon (Hansen et al., 2010; Karlsen et al., 2017). In the present study, feeding the full-fat insect meal, defatted insect meal and insect exoskeleton diets containing 1.4\% of chitin did not compromise growth performance in salmon, suggesting that this level of chitin may not be sufficient to cause negative effects on fish performance. Similarly, in previous studies, the presence of up to $1.2 \%$ and $2.1 \%$ of BSFL chitin in diets did not reduce growth 
rate in salmon (Weththasinghe et al., 2021a) and rainbow trout (Oncorhynchus mykiss) (Renna et al., 2017; Terova et al., 2019), respectively. The replacement of dietary protein with de-chitinised insect meal supported higher growth rate of fish, but decreased compared to full-fat insect meal, indicating BSFL chitin might have a positive effect on growth rate of salmon. The present results also showed that dietary inclusion of $7.2 \%$ insect exoskeleton improved FCR in fish than full-fat meal, which further confirmed that the exoskeleton fraction of BSFL might not have negative impact in salmon. On the other hand, it should be noted that the improved growth rate in fish fed de-chitinised meal diet can also be due to higher protein: lipid ratio in this diet.

Dietary inclusion of defatted insect meal, de-chitinised insect meal and insect exoskeleton reduced protein digestibility. This might partially be attributed to the presence of chitin in these diets; $1.4 \%$ in defatted meal and exoskeleton diets and $0.5 \%$ in de-chitinised meal diet. The exoskeleton of BSFL contains non-protein $\mathrm{N}$ from chitin and amino acids bound to a matrix (Finke, 2007), and thus probably have a low digestibility. The chitin digestibility capacity of salmon is low (13-40\%) (Olsen et al., 2006), leading to increased faecal $N$ excretion. The protein content was calculated as total $\mathrm{N} \times 6.25$, which overestimate the protein content in the faeces and consequently underestimate the ADC of protein. In addition, chitin might reduce the availability of insect protein for protease enzymes (Henry et al., 2015) or activity of protease enzymes (Belghit et al., 2018; Muzzarelli, 1980). On the other hand, full-fat insect meal diet also contained similar level of chitin as defatted meal and exoskeleton diets, but the full-fat insect meal diet did not reduce the ADC of protein in the present study. The chitin may lead to a reduced protein digestibility in fish, but in accordance with the present study and other studies, limited effect on protein digestibility in salmon (Fisher et al., 2020) and rainbow trout (Melenchón et al., 2021) fed BSFL meal has been reported.

Despite the reduced ADC of protein, the inclusion of meals or fractions of insects did not compromise protein retention. In line with the present results, BSFL meal in diets for salmon (Weththasinghe et al., 2021a) and rainbow trout (Melenchón et al., 2021) did not affect protein retention. In the present study, dietary inclusion of defatted insect meal even increased digested protein retention in salmon compared to both the control diet and the full-fat meal diet. In defatted insect meal fed fish, this was also accompanied by lower FCR compared to the fish fed full-fat meal. Thus, the replacement of $15 \%$ of dietary protein with defatted insect meal gave better feed utilisation than the full-fat insect meal. This emphasised the importance of applying a defatting process as a strategy to improve the nutritional value of BSFL.
Neither the insect meals nor the fractions adversely affected ADC of lipid in the present study. In several treatments, the lipid retention values were above $100 \%$. Similarly, Weththasinghe et al. (2021a) also reported lipid retention values above $100 \%$ in salmon, whereas Dumas et al. (2018) reported efficiency of lipid deposition values above $100 \%$ in rainbow trout, and indicated lipid synthesis outweighed lipid catabolism. The insect diets gave similar lipid retentions as the control diet, except for the de-chitinised meal diet which gave a higher lipid retention as well as LER in the present study. The lauric acid is shown a larger extent to be oxidised and a lesser extent to be deposited, resulting in reduced tissue lipid deposition (Belghit et al., 2019b; Renna et al., 2017) and subsequently reduced lipid retention. However, in the present study, de-chitinised meal diet with the highest proportion of lauric acid, had the highest lipid retention, indicating lipid deposited rather than oxidation. This is most likely due to the lower lipid content in this diet. On the other hand, the lower lipid retention in fish fed full-fat meal diet compared to other insect diets, might indicate a higher utilisation of energy from lipid, thus increasing the amount of dietary protein used for tissue synthesis due to a protein sparing effect (Francis and Turchini, 2017; Karalazos et al., 2011) and subsequently improved fish growth.

Corresponding to the higher retention of digested protein, defatted insect meal reduced the dissolved $\mathrm{N}$ discharges in salmon. Furthermore, the diets containing full-fat insect meal and de-chitinised insect meal reduced faecal $P$ excretion indicating improved $\mathrm{P}$ digestibility, whereas the fish fed the diet containing defatted insect meal showed higher $\mathrm{P}$ retention. This indicates that the P in BSFL might be more bioavailable than the $\mathrm{P}$ in fishmeal and plant protein sources. Thus, the present results suggest that feeding fish with diets containing full-fat, defatted or dechitinised insect meals reduced environmental impact of salmon production by reducing either dissolved $\mathrm{N}$ or faecal P excretion. On the other hand, feeding diets with defatted meal, de-chitinised meal and exoskeleton also increased environmental impact by increasing faecal $\mathrm{N}$ excretion.

\section{Conclusions}

In commercial production, less processed full-fat insect meal is more resource-efficient because processing of BSFL to remove lipid or exoskeleton fractions is an additional cost. It is, thus, important to determine if further processing of BSFL is necessary. In the present study, the full-fat insect meal improved feed intake and growth rate in salmon when replacing $15 \%$ of dietary protein from fishmeal and plant protein sources, although defatted meal gave better feed utilisation than full-fat meal. The present results suggest that BSFL might be optimal to use in less processed fullfat form in diets for salmon compared with processing to 
remove the lipid and exoskeleton fractions. However, the inclusion of lipid-rich full-fat and de-chitinised insect meals in the diet numerically reduced hardness, expansion, and water stability of the pellets. Future studies are needed to optimise the use of BSFL in extruded fish diets.

\section{Supplementary material}

Supplementary material can be found online at https://doi. org/10.3920/JIFF2021.0094

Table S1. Fatty acid composition (\% of total fatty acids) of black soldier fly larvae oil.

\section{Acknowledgements}

The present study was financially supported by the SureAqua Nordic Center of Excellence (Grant no. 82342) and the Research Council of Norway (RCN), BioTek 2021/ Havbruk Biofeed (Grant no. 229003). We are greatly thankful to Ricardo Tavares Benicio and Bjørn Reidar Hansen for their help in conducting fish experiment and sampling.

\section{Conflict of interest}

The authors declare no competing conflicts of interest.

\section{References}

Askarian, F., Zhou, Z., Olsen, R.E., Sperstad, S. and Ringø, E., 2012. Culturable autochthonous gut bacteria in Atlantic salmon (Salmo salar L.) fed diets with or without chitin. Characterization by $16 \mathrm{~S}$ rRNA gene sequencing, ability to produce enzymes and in vitro growth inhibition of four fish pathogens. Aquaculture 326-329: 1-8. https://doi.org/10.1016/j.aquaculture.2011.10.016

Austreng, E., 1978. Digestibility determination in fish using chromic oxide marking and analysis of contents from different segments of the gastrointestinal tract. Aquaculture 13: 265-272. https://doi. org/10.1016/0044-8486(78)90008-X

Baeverfjord, G., Refstie, S., Krogedal, P. and Åsgård, T., 2006. Low feed pellet water stability and fluctuating water salinity cause separation and accumulation of dietary oil in the stomach of rainbow trout (Oncorhynchus mykiss). Aquaculture 261: 1335-1345. https://doi. org/10.1016/j.aquaculture.2006.08.033

Bandyopadhyay, S. and Rout, R.K., 2001. Aquafeed extrudate flow rate and pellet characteristics from low-cost single-screw extruder. Journal of Aquatic Food Product Technology 10: 3-15. https://doi. org/10.1300/J030v10n02_02

Barroso, F.G., De Haro, C., Sánchez-Muros, M.-J., Venegas, E., Martínez-Sánchez, A. and Pérez-Bañón, C., 2014. The potential of various insect species for use as food for fish. Aquaculture 422423: 193-201. https://doi.org/10.1016/j.aquaculture.2013.12.024
Belghit, I., Liland, N.S., Gjesdal, P., Biancarosa, I., Menchetti, E., Li, Y., Waagbø, R., Krogdahl, Å. and Lock, E.-J., 2019a. Black soldier fly larvae meal can replace fish meal in diets of sea-water phase Atlantic salmon (Salmo salar). Aquaculture 503: 609-619. https:// doi.org/10.1016/j.aquaculture.2018.12.032

Belghit, I., Liland, N.S., Waagbø, R., Biancarosa, I., Pelusio, N., Li, Y., Krogdahl, Å. and Lock, E.-J., 2018. Potential of insect-based diets for Atlantic salmon (Salmo salar). Aquaculture 491: 72-81. https:// doi.org/10.1016/j.aquaculture.2018.03.016

Belghit, I., Waagbø, R., Lock, E.J. and Liland, N.S., 2019b. Insectbased diets high in lauric acid reduce liver lipids in freshwater Atlantic salmon. Aquaculture Nutrition 25: 343-357. https://doi. org/10.1111/anu.12860

Caligiani, A., Marseglia, A., Leni, G., Baldassarre, S., Maistrello, L., Dossena, A. and Sforza, S., 2018. Composition of black soldier fly prepupae and systematic approaches for extraction and fractionation of proteins, lipids and chitin. Food Research International 105: 812820. https://doi.org/10.1016/j.foodres.2017.12.012

Dumas, A., Raggi, T., Barkhouse, J., Lewis, E. and Weltzien, E., 2018. The oil fraction and partially defatted meal of black soldier fly larvae (Hermetia illucens) affect differently growth performance, feed efficiency, nutrient deposition, blood glucose and lipid digestibility of rainbow trout (Oncorhynchus mykiss). Aquaculture 492: 24-34. https://doi.org/10.1016/j.aquaculture.2018.03.038

Finke, M.D., 2007. Estimate of chitin in raw whole insects. Zoo Biology 26: 105-115. https://doi.org/10.1002/zoo.20123

Finke, M.D., 2013. Complete nutrient content of four species of feeder insects. Zoo Biology 32: 27-36. https://doi.org/10.1002/zoo.21012

Fisher, H.J., Collins, S.A., Hanson, C., Mason, B., Colombo, S.M. and Anderson, D.M., 2020. Black soldier fly larvae meal as a protein source in low fish meal diets for Atlantic salmon (Salmo salar). Aquaculture 521: 734978. https://doi.org/10.1016/j. aquaculture.2020.734978

Francis, D.S. and Turchini, G.M., 2017. Retro-engineering the protein sparing effect to preserve n-3 LC-PUFA from catabolism and optimise fish oil utilisation: a preliminary case study on juvenile Atlantic salmon. Aquaculture 468: 184-192. https://doi. org/10.1016/j.aquaculture.2016.10.013

Hansen, J.Ø., Penn, M., Øverland, M., Shearer, K.D., Krogdahl, Å., Mydland, L.T. and Storebakken, T., 2010. High inclusion of partially deshelled and whole krill meals in diets for Atlantic salmon (Salmo salar). Aquaculture 310: 164-172. https://doi.org/10.1016/j. aquaculture.2010.10.003

Hansen, J.Ø., Shearer, K.D., Øverland, M., Penn, M.H., Krogdahl, Å., Mydland, L.T. and Storebakken, T., 2011. Replacement of LT fish meal with a mixture of partially deshelled krill meal and pea protein concentrates in diets for Atlantic salmon (Salmo salar). Aquaculture 315: 275-282. https://doi.org/10.1016/j.aquaculture.2011.02.038

Helland, S.J., Grisdale-Helland, B. and Nerland, S., 1996. A simple method for the measurement of daily feed intake of groups of fish in tanks. Aquaculture 139: 157-163. https://doi.org/10.1016/00448486(95)01145-5

Henry, M., Gasco, L., Piccolo, G. and Fountoulaki, E., 2015. Review on the use of insects in the diet of farmed fish: past and future. Animal Feed Science and Technology 203: 1-22. https://doi.org/10.1016/j. anifeedsci.2015.03.001 
Hua, K. and Bureau, D.P., 2009. Development of a model to estimate digestible lipid content of salmonid fish feeds. Aquaculture 286: 271-276. https://doi.org/10.1016/j.aquaculture.2008.09.028

Ilo, S., Schoenlechner, R. and Berghofe, E., 2000. Role of lipids in the extrusion cooking processes. Grasas y Aceites 51: 97-110. https:// doi.org/10.3989/gya.2000.v51.i1-2.410

Karalazos, V., Bendiksen, E.Å., Dick, J.R., Tocher, D.R. and Bell, J.G., 2011. Influence of the dietary protein: lipid ratio and fish oil substitution on fatty acid composition and metabolism of Atlantic salmon (Salmo salar) reared at high water temperatures. British Journal of Nutrition 105: 1012-1025. https://doi.org/10.1017/ S0007114510004605

Karlsen, Ø., Amlund, H., Berg, A. and Olsen, R.E., 2017. The effect of dietary chitin on growth and nutrient digestibility in farmed Atlantic cod, Atlantic salmon and Atlantic halibut. Aquaculture Research 48: 123-133. https://doi.org/10.1111/are.12867

Kothakota, A., Jindal, N. and Thimmaiah, B., 2013. A study on evaluation and characterization of extruded product by using various by-products. African Journal of Food Science 7: 485-497. https:// doi.org/10.5897/AJFS2013.1065

Lock, E.R., Arsiwalla, T. and Waagbø, R., 2016. Insect larvae meal as an alternative source of nutrients in the diet of Atlantic salmon (Salmo salar) postsmolt. Aquaculture Nutrition 22: 1202-1213. https://doi.org/10.1111/anu.12343

Makkar, H.P.S., Tran, G., Heuzé, V. and Ankers, P., 2014. Stateof-the-art on use of insects as animal feed. Animal Feed Science and Technology 197: 1-33. https://doi.org/10.1016/j. anifeedsci.2014.07.008

McCleary, B.V., Solah, V. and Gibson, T.S., 1994. Quantitative measurement of total starch in cereal flours and products. Journal of Cereal Science 20: 51-58. https://doi.org/10.1006/jcrs.1994.1044.

Melenchón, F., Larrán, A.M., De Mercado, E., Hidalgo, M.C., Cardenete, G., Barroso, F.G., Fabrikov, D., Lourenço, H.M., Pessoa, M.F. and Tomás-Almenar, C., 2021. Potential use of black soldier fly (Hermetia illucens) and mealworm (Tenebrio molitor) insectmeals in diets for rainbow trout (Oncorhynchus mykiss). Aquaculture Nutrition 27: 491-505. https://doi.org/10.1111/anu.13201

Müller, A., Wolf, D. and Gutzeit, H.O., 2017. The black soldier fly, Hermetia illucens - a promising source for sustainable production of proteins, lipids and bioactive substances. Zeitschrift für Naturforschung C72: 351-363. https://doi.org/10.1515/znc-20170030

Muzzarelli, R.A.A., 1980. Immobilization of enzymes on chitin and chitosan. Enzyme and Microbial Technology 2: 177-184. https:// doi.org/10.1016/0141-0229(80)90044-7

National Research Council (NRC), 2011. Nutrient requirements of fish and shrimp. National Academies Press, Washington, DC, USA.

Nogales-Mérida, S., Gobbi, P., Józefiak, D., Mazurkiewicz, J., Dudek, K., Rawski, M., Kierończyk, B. and Józefiak, A., 2019. Insect meals in fish nutrition. Reviews in Aquaculture 11: 1080-1103. https:// doi.org/10.1111/raq.12281

O’Fallon, J.V., Busboom, J.R., Nelson, M.L. and Gaskins, C.T., 2007. A direct method for fatty acid methyl ester synthesis: application to wet meat tissues, oils, and feedstuffs. Journal of Animal Science 85: 1511-1521. https://doi.org/10.2527/jas.2006-4.91
Olsen, R.E., Suontama, J., Langmyhr, E., Mundheim, H., Ringø, E., Melle, W., Malde, M.K. and Hemre, G.I., 2006. The replacement of fish meal with Antarctic krill, Euphausia superba in diets for Atlantic salmon, Salmo salar. Aquaculture Nutrition 12: 280-290. https://doi.org/10.1111/j.1365-2095.2006.00400.x

Ottoboni, M., Spranghers, T., Pinotti, L., Baldi, A., De Jaeghere, W. and Eeckhout, M., 2018. Inclusion of Hermetia Illucens larvae or prepupae in an experimental extruded feed: process optimisation and impact on in vitro digestibility. Italian Journal of Animal Science 17: 418-427. https://doi.org/10.1080/1828051X.2017.1372698

Øverland, M., Sørensen, M., Storebakken, T., Penn, M., Krogdahl, Å. and Skrede, A., 2009. Pea protein concentrate substituting fish meal or soybean meal in diets for Atlantic salmon (Salmo salar) - effect on growth performance, nutrient digestibility, carcass composition, gut health, and physical feed quality. Aquaculture 288: 305-311. https://doi.org/10.1016/j.aquaculture.2008.12.012

Park, S.I., Chang, B.S. and Yoe, S.M., 2014. Detection of antimicrobial substances from larvae of the black soldier fly, Hermetia illucens (Diptera: Stratiomyidae). Entomological Research 44: 58-64. https:// doi.org/10.1111/1748-5967.12050

Park, S.-I., Kim, J.-W. and Yoe, S.M., 2015. Purification and characterization of a novel antibacterial peptide from black soldier fly (Hermetia illucens) larvae. Developmental \& Comparative Immunology 52: 98-106. https://doi.org/10.1016/j.dci.2015.04.018

Pathania, S., Singh, B., Sharma, S., Sharma, V. and Singla, S., 2013. Optimization of extrusion processing conditions for preparation of an instant grain base for use in weaning foods. International Journal of Engineering Research and Applications 3: 1040-1049.

Ravi, H.K., Degrou, A., Costil, J., Trespeuch, C., Chemat, F. and Vian, M.A., 2020. Effect of devitalization techniques on the lipid, protein, antioxidant, and chitin fractions of black soldier fly (Hermetia illucens) larvae. European Food Research and Technology 246: 2549-2568. https://doi.org/10.1007/s00217-020-03596-8

Rawski, M., Mazurkiewicz, J., Kierończyk, B. and Józefiak, D., 2020. Black soldier fly full-fat larvae meal as an alternative to fish meal and fish oil in Siberian sturgeon nutrition: the effects on physical properties of the feed, animal growth performance, and feed acceptance and utilization. Animals 10: 2119. https://doi. org/10.3390/ani10112119

Renna, M., Schiavone, A., Gai, F., Dabbou, S., Lussiana, C., Malfatto, V., Prearo, M., Capucchio, M.T., Biasato, I., Biasibetti, E., De Marco, M., Brugiapaglia, A., Zoccarato, I. and Gasco, L., 2017. Evaluation of the suitability of a partially defatted black soldier fly (Hermetia illucens L.) larvae meal as ingredient for rainbow trout (Oncorhynchus mykiss Walbaum) diets. Journal of Animal Science and Biotechnology 8: 57. https://doi.org/10.1186/s40104-017-0191-3

Shiau, S.-Y. and Yu, Y.-P., 1999. Dietary supplementation of chitin and chitosan depresses growth in tilapia, Oreochromis niloticus $\times$ O. aureus. Aquaculture 179: 439-446. https://doi.org/10.1016/ S0044-8486(99)00177-5 
Shomorin, G.O., Storebakken, T., Kraugerud, O.F., Øverland, M., Hansen, B.R. and Hansen, J.Ø., 2019. Evaluation of wedge wire screen as a new tool for faeces collection in digestibility assessment in fish: the impact of nutrient leaching on apparent digestibility of nitrogen, carbon and sulphur from fishmeal, soybean meal and rapeseed mealbased diets in rainbow trout (Oncorhynchus mykiss). Aquaculture 504: 81-87. https://doi.org/10.1016/j.aquaculture.2019.01.051

Simon, C.J., Truong, H., Habilay, N. and Hines, B., 2021. Feeding behaviour and bioavailability of essential amino acids in shrimp Penaeus monodon fed fresh and leached fishmeal and fishmealfree diets. Animals 11: 847. https://doi.org/10.3390/ani11030847

Skřivanová, E., Marounek, M., Benda, V. and Březina, P., 2006. Susceptibility of Escherichia coli, Salmonella sp and Clostridium perfringens to organic acids and monolaurin. Veterinarni Medicina 51: 81-88.

Spranghers, T., Michiels, J., Vrancx, J., Ovyn, A., Eeckhout, M., De Clercq, P. and De Smet, S., 2018. Gut antimicrobial effects and nutritional value of black soldier fly (Hermetia illucens L.) prepupae for weaned piglets. Animal Feed Science and Technology 235: 33-42. https://doi.org/10.1016/j.anifeedsci.2017.08.012
Terova, G., Rimoldi, S., Ascione, C., Gini, E., Ceccotti, C. and Gasco, L., 2019. Rainbow trout (Oncorhynchus mykiss) gut microbiota is modulated by insect meal from Hermetia illucens prepupae in the diet. Reviews in Fish Biology and Fisheries 29: 465-486. https://doi. org/10.1007/s11160-019-09558-y

Wang, Y.-S. and Shelomi, M., 2017. Review of black soldier fly (Hermetia illucens) as animal feed and human food. Foods 6: 91. https://doi.org/10.3390/foods6100091

Weththasinghe, P., Hansen, J.Ø., Nøkland, D., Lagos, L., Rawski, M. and Øverland, M., 2021a. Full-fat black soldier fly larvae (Hermetia illucens) meal and paste in extruded diets for Atlantic salmon (Salmo salar): effect on physical pellet quality, nutrient digestibility, nutrient utilization and growth performances. Aquaculture 530: 735785. https://doi.org/10.1016/j.aquaculture.2020.735785

Weththasinghe, P., Lagos, L., Cortés, M., Hansen, J.Ø. and Øverland, M., 2021b. Dietary inclusion of black soldier fly (Hermetia Illucens) larvae meal and paste improved gut health but had minor effects on skin mucus proteome and immune response in Atlantic salmon (Salmo Salar). Frontiers in Immunology 12: 599530. https://doi. org/10.3389/fimmu.2021.599530 
